\title{
Disney IP Industry Development Strategy
}

\author{
Yuxin Zhang ${ }^{1}$ \\ ${ }^{I}$ Economy and Management College, Fujian Agriculture and Forestry University, Fuzhou, 350002, China \\ Corresponding Author's Email:876229796@qq.com
}

\begin{abstract}
With the enhancement of the country's comprehensive strength and economic development, the steady improvement of spiritual civilization construction, new literary works have sprung up, and many domestic IP are born on this background. However, the development of China's IP industry is still a long way off due to the nonstandard industrial management and lack of development experience. Referring to the successful commercial road of Disney super IP, the author tries to sum up experience, use the theory of use and satisfaction to learn the essence, and put forward some suggestions on the localization of IP industry mode, aiming at the rapid development of China's IP industry.
\end{abstract}

Keywords: Super IP, localization, Chinese culture.

\section{INTRODUCTION}

The best enterprise, the best partner, the best product, Disney IP development skills. Although the box office of Chinese films is not expected to be ideal this year, Disney, one of the six major Hollywood film companies, has performed well. In addition to "crazy animal city", which broke the box office record of Chinese animated films, the opening of Shanghai Disneyland Resort also stimulated the consumption of Disney concept. As the world's largest franchisor with 11 over one billion dollar "IP" (character series), Disney's authorized consumer goods business has also made remarkable achievements in the Chinese market, maintaining 33\% growth for two consecutive years, accounting for more than $50 \%$ of China's animation market share. In September this year, Disney held a "Walt Disney Greater China region 2017 kick off meeting" in Shanghai for licensees. At the meeting, Lin Jiawen, vice president and general manager of Disney's consumer products and interactive China, announced that Disney's film box office and consumer goods business in Greater China in fiscal 2016 both reached record highs, achieving record growth since 2005, and also announced its four major brands Disney, Pixar, marvel and Star Wars consumer goods strategy in China in fiscal 2017.

\section{DISNEY'S IP SERVICE SYSTEM}

Walt Disney Company has been established for more than 80 years. It is one of the leading enterprises in the global entertainment industry. It has become a large entertainment enterprise group with film and television production as the core, integrating theme park resort, consumer products, media network and book publishing. Disney has a number of branches, almost covering the entire cultural industry and forming a relatively complete industrial chain. According to the financial report of Disney in 2015, nearly 60\% of the total revenue of Disney industry chain is driven by IP, and the related business sectors include theme park $(30.8 \%)$, film and television entertainment (14\%), consumer goods $(8.6 \%)$ and interactive media (2.2\%)[1]. Although only $14 \%$ of the box office revenue is directly generated by IP content, together with theme parks, consumer products and interactive media. Which are a series of industries built around IP content resources, Disney's revenue is actually more than half. It can be said that the development of IP resources is the strategic core of Disney's whole industry chain marketing, and it is its focus on IP marketing that continuously injects development power into the nearly 100 year history of Disney's "animation kingdom". The so-called IP is the abbreviation of English intellectual property, which originally means "intellectual (property) ownership" or "intellectual (property) ownership", also known as intellectual achievement right. For the cultural industry, having high-value core assets is to produce high-quality content intellectual property. Over the past few decades, Disney has created countless vivid images, no matter the most classic Mickey and his friends series, the successive appearance of more than a dozen Disney princesses with different styles, or the rabbit police officer Judy and fox Nick in the national warm man and crazy animal city. Each image and its related films have 
produced its own content IP, which dominates the Disney series so that the audience of different IP can transform each other.

\section{DISNEY'S CONTENT IP CREATION}

IP building is not only the source of Disney industry chain, but also the core resource. Disney's core IP lies in the creation of characters, plots and scenes. In order to make the characters and stories more popular, Disney always adheres to some core principles in this process: it adheres to the strategy of keeping pace with the times in the shaping of animation stars, constantly introduces new character images with characteristics of the times, and continues to market the classic IP which has been successful, so that all kinds of subdivided audiences can find their favorite images and take their seats in the right place We should strengthen the sense of participation and experience; adhere to the localization strategy, replace different images and cultural backgrounds, and adopt different publicity means when promoting to different international markets; carry out deep-rooted emotional marketing and happy marketing around the eternal themes of human beings, such as family, love, friendship; train fans for animation stars, and speak for stars from all walks of life And boost, drive the transformation between fans of these stars, so as to liven up the fan economy[2].

\section{DISNEY'S IP BRAND AUTHORIZATION AND CONSUMER GOODS MARKETING}

Besides creating and consolidating content IP, commodity authorization is one of the most basic and important ways in the process of IP consumer product development and continuous realization, and it becomes an important source of Disney profit and a multi-party profit model. At present, Disney has more than 3000 authorized companies worldwide, and has more than 100 authorized operators in mainland China, selling more than 100000 products related to Disney cartoon image, which makes the classic image of Disney almost covering people's daily life and clothing. UNIQLO Disney cooperation T-shirt, Master Kang's advertising implantation on Disney metro line, the U.S. captain shield Zongzi of WuFangzhai, Disney commemorative stamp commemorative note issued by ICBC Cross border cooperation generated by Disney authorization is full of daily life, which has an invisible impact on people's consumption choices. The company grants third parties the right to use the roles and other IP in Disney film and television and charge copyright fees from wholesale or retail prices in a fixed proportion[3]. Meanwhile, Disney will design and produce specific products based on the company's classic roles, films and TV programs, and plan unique thematic and cyclical promotional activities for retailers. Disney park and its sales, catering and other surrounding businesses are also important markets to strengthen Disney content IP and promote realization. According to statistics, Disney's revenue in consumer goods and derivatives alone reached 4.5 billion U.S dollars in 2015 .

Due to the strong connection and distinct consumption characteristics between IP consumer goods and IP content, they have strong liquidity and brand effect among IP fans. The relationship between content consumption and consumer goods consumption is not only relatively independent, but also complementary and promoting. Relative independence makes consumers have more free choice space and spontaneous autonomy for the consumption behavior of content and consumer goods, and brings more soft and more acceptable consumption feeling; it is the support of content for consumer goods and the feedback of consumer goods revenue for content that make the two form a virtuous circle in the inseparable relationship. Fans' purchase of preferred IP consumer derivatives is not a simple commercial purchase behavior, but through another form to complete the emotional expression and life implantation of their favorite IP. Through the purchase of consumer goods, consumers realize the role-playing, the sense of participation and experience with role companionship, and obtain happiness at the same time. The fans formed by this kind of happiness transmission are the most loyal consumers, and their directional consumption has the potential to create high economic benefits.

\section{DISNEY IP INDUSTRY DEVELOPMENT STRATEGY}

\subsection{Expanding categories}

"Creating local design, focusing on digital trends and deepening consumer interaction are Disney's three major strategies. We have designed many products that are different from the international market and specifically for the Chinese market." Lin recalled that Disney and its Chinese partners signed licensing agreements in 1991. After 25 years of development, the number of licensors in Greater China has reached 600. "Of the 600 licensees, 400 are in mainland China, 100 in Hong Kong and 100 in Taiwan." Lin Jiawen said that last year Disney released 300 franchisees, mainly in the mainland market, which means that the mainland market has increased by 100 franchisees in the past year[4]. In addition, the 600 companies also include some of the former international partners who have entered the Chinese market. Among the authorized categories of Disney, there are mainly clothing, furniture, electronics, toys, beauty food, publishing, etc. in recent years, some new categories have been added, such as cars, etc. Among all the licensors, clothing accounts for a large proportion. From the perspective of consumers, the fastest growing is "young consumers" -- in the past two 
years, the proportion of young people in Disney Greater China's consumer goods consumption was $25 \%$, now it is $34 \%$, with an annual growth rate of $50 \%$.

Disney's Greater China Product Creative Department told 21st Century Business Review (hereinafter referred to as 21cbr) that Disney's criteria for selecting licensees are reflected in three aspects: company size, product standards and authorized amount. "We have very high product and company compliance standards, and our internal audit is also very strict. For example, products related to marvel and star wars have to be sent to international agencies and the US headquarters for approval. We need to determine whether the licensors use the images correctly and whether the products are against the story. In addition, the amount of authorization fee is increasing every year, and the standard depends on the category. If Disney has a relatively small category, we are willing to cooperate, and the authorization fee may be lower; if there is no shortage of this category, the threshold may be higher. " Lin Jiawen said that Disney will not limit the number of licensees in a certain category, but has higher requirements on the entry threshold. He used three "best" to describe them: the best enterprise, the best partner and the best product. Lin Jiawen told "21cbr" that Disney will collect a minimum license fee from the franchisor, and then divide it according to the sales volume of the product. "Simply put, the better our partners sell, the more we earn." In order to provide more convenient services to licensors and retailers all over the country, Disney consumer products department also decided to join $\mathrm{B} 2 \mathrm{~B}$ e-commerce platform 1688.com to establish a B2B platform connecting licensors and retailers. "We hope that through this platform, we can help licensors wholesale more products to third, fourth and fifth tier cities, and sell different products to consumers more quickly "I'm not in it." Lin Jiawen explained to 21cbr.

\section{2."Advance" authorization}

The outside world has always been curious about Disney's "IP" development system and process. In fact, from September to October, Disney holds a large authorization Conference (the "start-up meeting"), and a small promotion will be conducted in March next year. The annual mid year report for the licensors will be issued, which aims to introduce the business potential of Disney brands and the investment and potential influence of future content production to partners. At the launch conference in September this year, Disney China introduced the following contents to the authorized companies: Mickey, Minnie and Disney Princess have been popular; the real life movie "beauty and beast" adapted from Disney classic animation is being produced and is expected to be released in 2017; the general mobilization of the car is the first male character series in the world, and Lightning McQueen will be in the latest A "car mobilization 3" meets the audience again; the manway superheroes will introduce new series "strange doctor", "Galaxy guard 2" and "thunder god 3" will be released successively; Star Wars Series "grand theft 1: Star Wars exodus" will be on the screen again this year, with the leading lineup including Jiang Wen and Zhen Zidan[5].

The new films mentioned above are also the cooperation content that Disney hopes to focus on promoting to licensees. Take "crazy animal city", which has set a box office record of 1.5 billion yuan in China this year, as an example. 12 months or more before the movie was released, Disney had already begun to "blow the wind" to the licensors. As for whether to choose new characters for cooperation, it is a great test of the judgment ability of the licensors. "In order to ensure that the products can be put on the market at the same time as the film, Disney will negotiate with the licensors one year before the film is released, and even start to popularize the film content to the licensors 18 months before the film is released. We need to make full use of 12-18 months to allow authorized manufacturers to develop products and make molds. " Lin Jiawen explained. If the franchisor decides to cooperate with Disney, then it needs to deal with the product creative department next. The staff of product creative department are responsible for different product fields, and the design team has about dozens of people. At the annual kick-off meeting, the authorized chamber of commerce obtains the product catalog magazine "d attitude" produced by the design department, which provides product concept, creativity and reference for the authorized suppliers. For example, this year, the product creativity department has designed a set of "four treasures of study" matching with red sandalwood according to the elements of Star Wars series.

In addition, every year, Disney product creative department formulates creative strategies for authorized consumer products in the next year. Ouyang Dedong, vice president of product creativity of Disney Greater China, said that the three major directions of Disney consumer products in the new year are "intelligent products, healthy life and" her "economy", which means that Disney hopes to guide more licensees to participate in the commodity research and development in these fields. With the new story content and concept products provided by the design team, licensors can choose and design according to their own needs. Next, the franchisor needs to submit the product design to Disney for approval. Lin Jiawen disclosed that sometimes in order to determine a product, the design team has to approve it five to six times[6]. According to the financial report, consumer products accounted for $9.58 \%$ of Disney's global revenue in fiscal 2015, totaling US $\$ 5.027$ billion, of which the profit was US $\$ 1.752$ billion. 


\section{CONCLUSION}

In China, the growth momentum of Disney's consumer products business is still strong, but Lin Jiawen still hopes to use new means to stimulate growth, such as games. Because of the business merger, Lin Jiawen's management work has expanded again, including the licensing department, publishing department, Disney English, Disney Store, e-commerce and game department. "My future idea is to connect games and consumer goods. For example, consumers may buy some products on games or connect e-commerce through games." Lin Jiawen said that games are a bigger market than movies in China, which will be a major development direction of Disney in the future.

\section{REFERENCES}

[1] $\mathrm{Wu}$ Zehua. The driving prospect of vr virtual shooting for the film industry -- Taking the new version of lion king in 2019 as an example [J]. Media Forum,vol. 4, no. 2, pp. 105-106, 2021.

[2] Qi Ji. The current situation and innovation trend of children's IP books -- Taking Disney books as an example [J]. Journal of news research,vol. 11, no. 11, pp. 176-177, 2020.

[3] Zhang Yuqi. Disney's IP Product licensing model in China and its inspiration [J]. It manager world,vol. 23, no. 9, pp. 111-112114, 2020.

[4] Ding CHUANNING. The success of Disneyland in the new media era $[\mathrm{J}]$. Media Forum,vol. 2, no. 15, pp. 16-17, 2019.

[5] Kang Ying. Will cultural and tourism IP become the next big money in the tourism market [J]. Contemporary tourism,vol. 18, no. 5, pp. 20-21, 2020.

[6] Liu ya. Research and development mode of learning books based on international top IP Resources: a case study of Disney [J]. Journal of news research,vol. 10, no. 11, pp. 175-176, 2019. 